\title{
Cellers vekstfase forlenges ved glukosemangel
}

\section{Studier med encellede gjærceller viser at vekstfasen forlenges ved mangel på glukose. Denne kunnskapen kan kanskje utnyttes i kreftbehandling.}

Schizosaccharomyces pombe er encellede gjærceller som benyttes for å studere cellesyklusen. De ulike fasene i cellesyklusen er strengt regulert med interne sjekkpunkter. I tillegg er syklusen sensitiv for eksterne faktorer, bl.a. næring og stress. Når disse gjærcellene i laboratoriet adapteres til glukose-

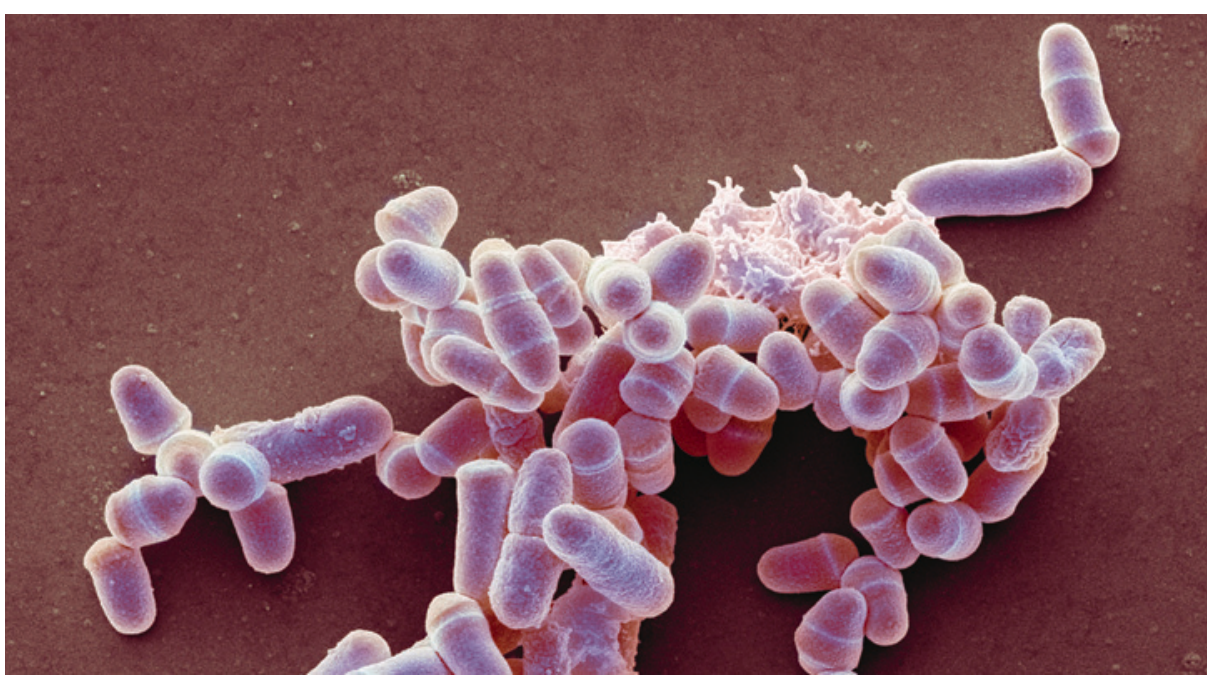

Illustrasjonsfoto: Science Photo Library

\section{$\emptyset$ ker antidepressiver selvmordsfaren?}

\section{Antidepressive legemidler $\varnothing$ ker ikke selvmordsfaren hos voksne, men gir mer selvmordstanker hos barn og unge.}

Selektive serotoninreopptakshemmere(SSRI) og serotonin- og noradrenalinreopptakshemmere (SNRI) er blant de mest forskrevne medikamentene mot depresjon, men det har vært uklart om disse medikamentene kan føre til økt selvmordsfare.

I en ny metaanalyse publisert i $B M J$ gikk forfatterne igjennom de kliniske studierapportene for SSRI- og SNRI-midler som er innlevert til det europeiske legemiddeltilsynet og til legemiddeltilsynet i Storbritannia (1). Slike rapporter er mer utfyllende, blant annet når det gjelder bivirkninger og potensielt skadelige effekter av medikamenter, enn originalartikler som publiseres i vitenskapelige tidsskrifter. Rapporter for 70 randomiserte kontrollerte studier med over 18000 pasienter ble inkludert, hvorav 11 studier omfattet barn og unge.

redusert medium, stopper de opp i 1-2 generasjoner før celledelingen gjenopptas. En tilstand med begrenset glukose kan minne om hva som skjer når celler vokser i en tumor.

I en nylig publisert studie er det vist at G2fasen, vekstfasen, forlenges ved glukosemangel (1). DNA er kopiert, mens mitotisk

$$
\text { re }
$$
responderer pă forandringer i tilgjengelig næring. Nytt i denne studien er hvordan disse to prosessene er koblet sammen. Wee1-proteinet kan være et attraktivt mål for kreftterapi, og Wee1-inhibitorer er allerede tatt $\mathrm{i}$ bruk $\mathrm{i}$ kliniske studier pga. dets rolle ved sjekkpunkt for DNA-skade og ved DNA-replikering. Det er spennende at resultater fra denne gjærstudien kan frembringe nye ideer for kombinasjonsterapi i prekliniske og kliniske studier, sier Grallert.

\section{Ruth Halsne \\ Tidsskriftet \\ Litteratur \\ 1. Masuda F, Ishii M, Mori A et al. Glucose restriction induces transient $\mathrm{G} 2$ cell cycle arrest extending cel- lular chronological lifespan. Sci Rep 2016; 6: 19629.}

Det ble ikke påvist signifikante forskjeller i totaldødelighet eller i forekomsten av selvmord, selvmordsforsøk, selvmordstanker eller rastløshet og bevegelsestrang, såkalt akatisi. Derimot ble det påvist signifikant mer aggressiv atferd i intervensjonsgruppen (oddsratio 1,93; $95 \%$ KI 1,26-2,95). For barn og unge ble det påvist en signifikant høyere selvmordsfare $(2,39$; KI 1,31-4,33), definert som selvmord, selvmordsforsøk og selvmordstanker, men ikke for selvmord og selvmordsforsøk alene. Forfatterne anbefaler at bruken av antidepressiver til barn og unge bør sterkt begrenses og mener at fremtidige systematiske oversiktsartikler må være basert på kliniske studierapporter for å få et sannere bilde av medikamenters virkninger og bivirkninger.

- Et problem med denne undersøkelsen er at den har definert suicidalitet meget bredt som alt fra selvmord, selvmordsfors $ø$ k eller forberedelser til selvmordsforsøk til villet egenskade og selvmordstanker, sier Lars Mehlum, professor i psykiatri ved Universitetet i Oslo. Når man ser nærmere på dataene som ligger bak, går det tydelig frem at det mest dreier seg om selvmordstanker. Det var ikke signifikant økt forekomst av selvmord eller selvmordsforsøk blant barn og unge som fikk antidepressive legemidler. Det er derfor ikke korrekt at studien bekrefter en økt risikoen for selvmord hos barn og unge, slik forfatterne påstår.

- Pasienter med økt risiko for selvmord blir fortsatt ekskludert i de fleste studier av antidepressive legemidler. I denne oversiktsartikkelen gjaldt dette om lag to tredeler av studiene. Dette gjør det vanskelig å trekke sikre konklusjoner om hvorvidt antidepressive legemidler øker eller reduserer risikoen for suicidal atferd hos dem som faktisk allerede har slik risiko.

\section{Ketil Slagstad \\ Tidsskriftet}

\section{Litteratur}

1. Sharma T, Guski LS, Freund N et al. Suicidality and aggression during antidepressant treatment: systematic review and meta-analyses based on clinical study reports. BMJ 2016; 352: i65. 